\title{
A Study of Consumer Behavior on Recycling of Fluorescent Lamps in São Paulo, Brazil
}

\author{
Mauro Maia Laruccia (Corresponding author) \\ School of Management, Pontifícia Universidade Católica de São Paulo and Universidade Braz Cubas \\ Rua Ministro de Godoi, 969, São Paulo 03138-010, Brazil \\ Tel: +55-11-8286-7467Ｅ-mail: mauro.laruccia@gmail.com
}

Jarbas Vargas Nascimento

Master Programme, Pontifícia Universidade Católica de São Paulo

Rua Ministro Godói, 969 - 4th floor, São Paulo 03138-010, Brazil

Tel: +55-11- 3670.8528Ｅ-mail: jvnf1@yahoo.com.br

Gilmar Jonas Deghi

School of Management, Faculdades Integradas Campos Salles

Rua Nossa Senhora da Lapa, 284, São Paulo 05072-000, Brazil

Tel: +55-11-3649-7000Ｅ-mail: gjdeghi@terra.com.br

Mamerto Granja Garcia

School of Management, Pontifícia Universidade Católica de São Paulo

Rua Ministro de Godoi, 969, São Paulo 03138-010, Brazil

Tel: +55-11-9887-9504Ｅ-mail: mamertog@gmail.com

Received: June 1, 2011 Accepted: August 12, $2011 \quad$ doi:10.5430/ijba.v2n3p101

\begin{abstract}
The purpose of this article is to understand consumer behavior on the disposal of fluorescent lamps used in Sao Paulo, Brazil. The research discusses the consumer's decision on recycling, environmental aspects of disposal of fluorescent lamps and reverse logistics. Regarding methodology procedures we used a survey on the basis of convenience, with a sample of 240 people. As a result, most people discard fluorescent lamps in the organic waste and considering the right place for disposal the selective collection and recycle post. However, the posts for selective collection are not prepared for the effective recycling of fluorescent lamps and components in Brazil.
\end{abstract}

Keywords: Consumer Behavior, Fluorescent Lamps, Reverse Logistics, Environment

\section{Introduction}

The Association of Lighting and Mercury Recyclers (ALMR) represent lamp recyclers is a U.S. related to Universal Waste Handlers and related equipment manufacturers. ALMR member companies network with each other so that lamps from anywhere in the country can be collected and recycled. The International Association of Lighting Maintenance Companies (NALMCO) represents lighting maintenance companies in the United States, which may provide spent lamp management recycling services as part of their lighting maintenance operations.

According to EPA, the amount of mercury in a fluorescent lamp ranges between 3.5 to 15 milligrams, depending on the type of fluorescent lamp, the manufacturer, and when the fluorescent lamp was manufactured. Although lighting manufacturers have greatly reduced the amount of mercury used in lighting over the past 20 years, they are not yet able to completely eliminate the need for mercury. Millions of mercury-containing lamps are sold in the United States each year, and most are improperly discarded. Although the amount of mercury in a single fluorescent lamp is small, 
collectively, large numbers of fluorescent lamps contribute to the amount of mercury that is released into the environment. EPA encourages the recycling of all mercury-containing lamps.

Brazil produces approximately 230 million tons of rubbish every day. This equates to every Brazilian generating over 500 grams of rubbish every day. Up to 30 percent of this rubbish is composed of recyclable materials such as plastics, glass, paper and metal cans.

In Brazil, in its 2003 report, the Brazilian Association of Lighting Industry (ABILUX) finds that 92.4\% of the mercury lamps come from industrial, commercial and service sectors. Only 7.6\% are from households. This demonstrates that the concern of proper disposal must be directed primarily to business (ABILUX, 2003).

Brazilian consumption is approximately 100 million fluorescent bulbs a year, and only $6 \%$ is recycled. Thus, it is the intervention of a government legislation to regulate the return of used fluorescent lamps, enabling their constituent materials are used as raw material in different production processes (Sanchez, 2007).

Fluorescent light bulbs should never be thrown away with common rubbish or included with regular recycling as they contain heavy metals. Of particular concern is mercury in the bulbs found in the form of vapor that is dangerous if released into the air. If a fluorescent light breaks and the vapor is inhaled it is suggested to seek medical attention. Mercury is a neurotoxin known to cause kidney and brain damage. Efforts made by the lighting industry to address concerns about disposal and the risk of mercury from lamps leaching into soil and water are commendable.

In Brazil it is common for improper disposal in landfills and municipal landfills, where lamps suffer damage and release of mercury vapor contaminant. Apart from the soil, the metal can contaminate air and water, varying their length of stay in the environment according to the local temperature (Raposo \& Roeser, 2000).

The need to recycle fluorescent lamps and return to its origin is necessary and appropriate way to develop this action can be obtained through reverse logistics, once the correct disposal benefits the environment, society and the local economy, and create new business opportunities in Brazil.

\section{Literature}

\subsection{The Consumer's Recycling Decision}

Concerns about conserving natural resources, studying disposition behaviors can provide valuable insights for the development of recycling programs around the world. For example, studies show that attitudes toward recycling influence waste recycling and recycling shopping behaviors. The motivation, ability and opportunities to recycle are the most useful variables to understanding consumer recycling (Hoyer \& Macinnis, 2009).

Marketing strategies indentify consumer needs and appeal to them through marketing tools. Sustainable strategies tell consumers that company or products are committed to their long-terns needs including environment. A company, which reduces energy, use and them thereby reduces air pollution is contributing to a quality of life that most people in the world should see sustained and improved for their own future and generations. Consumers in general respond both to perceived sincerely and environment.

Dahab et. al. (1995), states that "reducing, recycling, and reusing become important public policies with respect to the consumption and disposition of consumer goods, marketers have the opportunity to use consumer behavior concepts to explain differences in behavior and offer insights into program development".

Recycling decisions depend on what items the customer has purchased. Following the standard dynamic programming approach, we assume that, in the first stage, the consumer chooses the consumption mix based on the optimal disposal and recycling decisions in the second stage. The consumer makes the purchase decisions in the initial period anticipating optimal disposal afterwards so that it is appropriate to analyze the second stage disposal and recycle decision, taking as given the last purchase decisions.

Disposal consumer decisions have been study extensively in the literature. Although the primary reason for deposit-refund was to control the littering of beverage containers, this approach might also indirectly affect a municipality's decision to implement a curbside recycling program and try to stimulate the demand for recyclable materials, for example, offering tax incentives to firms that create new facilities that process recycled materials, or offered grants to promote such activities (Kinnaman, 2005).

The incentives behind and the extent of consumer participation in the recycling process, and its impact on the price of a recyclable product must, however, been largely left unexplored. While some papers are silent about consumers, others believe that consumers simply discard the scrap that is then retrieved by a scrap recovery sector. Discarding, rather than selling, the scrap simplifies the problem, as the product price then does not have to include the discounted scrap price. 
Nevertheless, to the extent that scrap sells at a positive price, some consumers may be motivated to sell instead (Baksi \& Van Long, 2009).

Although the intrinsic value of recycling for each consumer will be unique to that consumer, it is also likely to be influenced by social norms. In particular, the incentive for a customer to recycle can grow as more consumers around them develop recycling. Psychologists have noted signs of such social impact on individuals' motivation to engage in pro-environmental behavior such as recycling, energy conservation and reduced littering.

An individual's motivation for pro-environmental behavior can arise from two sources - personal norms and social norms. Personal norms are "self-expectations of behavior backed by the anticipation of self-enhancement or [self-]depreciation” (Schwartz \& Fleishman, 1978). Social norms, in contrast, are beliefs about what other people are doing or what other people think should be done ('injunctive' social norms). Social norms, according to psychologists, serve not only as a source of motivation but can also be used for defining personal norms.

Psychological studies thus suggest that social norms create a network effect that modifies each consumer's idiosyncratic (influenced by personal norms) motivation to recycle. We incorporate this phenomenon by assuming the existence of a network effect that modifies each consumer's idiosyncratic recycling cost.

\subsection{Fluorescent Lamps and Environment Aspects}

In this sub-item, fluorescent lamps will be addressed with environmental issues, in order to demonstrate the influences of this product in the environment.

The fluorescent lamp market in Brazil has never resulted a balance between direct and reverse flows. There is a large imbalance between the quantity of lamps manufactured and the number of lamps recycled. Brazil consumes approximately 100 million fluorescent bulbs a year and recycle only 6\%. Thus, it becomes necessary to change consumer behavior, as well as intervention by government legislation to reverse the rate of recycling and allow a better ratio of return of fluorescent lamps post-consumer materials to enable recycled used as raw material in production processes.

The ABILUX in its 2003 report considered that $92.4 \%$ of the mercury lamps come from industrial, commercial and service sectors. Only 7.6\% are from households. These figures demonstrate a concern for proper disposal should be directed, initially, for business. According to information from ABILUX, sales of Compact Fluorescent Lamps CFLs in Brazil in 2008 increased 25\% compared to last year, indicates that the trend is the continued growth of the sector.

Thus, it is essential to Life Cycle Assessment, or LCA to identify and recognize the environmental aspects of the stages of its manufacture, use, disposal and reuse. Through the LCA analyzes the processes of application of raw materials to product composition, production processes, packaging, transportation and distribution, and procedures for waste recovery and its subsequent operation. The LCA is crucial for obtaining environmental information products and business transparency about the impacts of their products sold (Güngör \& Gupta, 1999).

The technique of LCA, in the case of fluorescent lamps, shows that the post-consumer recycling is a method that enables the extension of the life cycle of its components. Thus, Life Cycle Assessment of fluorescent lamps contributes to the development of processes for recovery of waste, also known as aftermarket of the fluorescent lamp.

The fluorescent lamp has gained market share because of its various advantages: high efficiency, high durability, less heating of the environment, lower power consumption and different tonalities of color for adequacy a variety of environments.

By reverse logistics enables the fluorescent industry to consider the economic purpose of recycling companies and the secondary market raw materials, like recycling industry profits from the sale of materials recovered from post-consumer fluorescent lamps, and organizations can reduce costs when buying recycled raw material (Gregory \& Kirchain, 2008). In Brazil, common points of lamp disposal are landfills, which receive $94 \%$ of the lamps discarded and only $6 \%$ of lamps produced are properly destined in Brazil.

According to Environment Canada (2011), in humans the impact of mercury contamination can affect the health of specific organs of the body. The main routes of contamination are inhalation, skin contact, eye contact and ingestion.

\subsection{Reverse Logistics Management}

The American Council of Logistics Management (CLM) defines reverse logistics as 'The process of planning, implementing, and controlling the efficient, cost effective flow of raw materials, in-process inventory, finished goods and related information from the point of consumption to the point of origin for the purpose of recapturing value or proper disposal' (Vitasek, 2010). Generally speaking, reverse logistics management (RLM) includes topics such as 
disassembly, general and hazardous waste treatment, recycling, and disposal, in addition to typical logistics activities such as information flow, transportation, and warehousing (Fleischmann, 1997; Ravi \& Shankar, 2005).

Some prior RLM researches put emphasis on the reduction of gross cost, and identified the critical sectors (e.g. Li-Hsing, 2001 and $\mathrm{Hu}$ et al. 2002). Another group of researches focused on the optimal disassembly or recycling sequence are (Gerner et al. 2005; Johnson \& Wang, 1995; Penev \& Ron, 1996; Güngör \& Gupta, 2002 and Lambert, 1997). Das et al. (2000) developed a model with seven factors to assess disassembly effort and cost.

There are differences between the direct distribution channels and the reverse: while the direct distribution channels are the steps that produced the goods reach the ultimate consumer, the reverse distribution channels are the steps that the product returns to its post-consumer and post-sale (Polanco, 2007). The reverse logistics is divided into two categories of reverse flow with the same name: the post-consumer products and after sales. Both categories comprise the "reverse distribution channels", which contemplate various stages through the goods produced and consumed already back into the productive in some way (Souza, Santos \& Lima, 2007).

In general, the reverse distribution program requiring a sponsor by a lamp manufacturer or distributor, that include a business distributing lamps to its facilitate, requiring also, a sponsor that assumes responsibility for collection and recycling of spent lamps.

Currently there are three options for lamp disposal: land filling, incineration and recycling. For DiLouie (1994), recycling fluorescent lamps means to separate mercury from others component such glass and aluminum endcaps. Remanufacturing the glass can be by using into non-food containers or be used as filler into other aluminum products. The mercury could be distilled and used in thermometers and other products.

The responsibility collection, treatment, recovery, and disposal are also called 'extended producer responsibility (EPR)' in the literature (Spicer \& Johnson, 2004). Although hazardous waste problem is widely recognized, it is still very difficult to be thoroughly resolved in practice not only because of technological issues but also costs and social factors (Das et al., 2000).

Thus, to reduce the possibility of mercury contamination by improper disposal of fluorescent lamps from both the residential and commercial, it is necessary to plan for alternatives to the centralization of warehousing and transport of used lamps to its final disposal. The difficulty of disposing of lamps used in Brazil is due to the lack of collection points and the constant occurrence of faults in time to return the lamps.

Examples of environmental laws in other countries show that adoption of these in advance brings many benefits as they adapt the product manufacturers to potentially polluting strategies aimed at sustaining the environment, and providing mechanisms to develop the reverse flow of as usual. Thus, the objective is to understand consumer behavior on the disposal of fluorescent lamps used in São Paulo, Brazil.

\subsection{Environmental Regulations for Disposal of Lamps Post-consumer}

Legislation at the federal level for the disposal of product is still nonexistent in Brazil, and this lack reflects the weakness in domestic considers the lamp as a risk product. The Federal Constitution deals in general with the environmental aspects and assigns to the Public Authorities and society a duty to protect and preserve, but nothing specific about the disposal of lamps can be found in legislation.

In other countries, the fluorescent lamp is considered a product of proper disposal required, as in the Netherlands, which recycles no less than $83.3 \%$ of units discarded. According to Procel Info (2007), Brazilian center for information on energy efficiency, the Netherlands is the country that recycles more lamps in the world, followed by Germany and Belgium, who ruled 50\%. Norway contributes to the recycling of 33\%, the United States with 25\%, Spain with $14.3 \%$. Italy recycles $11 \%$ and France and Britain ruled $10 \%$ each. Brazil is far from reality in these countries, with about $6 \%$ of recycling all of their fluorescent lamps.

Before this point, some states and municipalities have already taken initiatives, and developed legislative bills and laws for the disposal of lamps, such as Rio Grande do Sul, Espirito Santo, São Paulo, Santa Catarina, Minas Gerais. In relation to municipalities, there are laws that refer to the disposal of bulbs in Americana (SP), Campinas (SP), and Caxias do Sul (RS).

In the state of Rio Grande do Sul Law 11187, of 1998, regulates the disposal of batteries and fluorescent lamps, by prohibiting the provision of public deposits of solid waste and its incineration. In Espirito Santo are two laws that deal with fluorescent lights, are they, Law 6291 of July 11, 2000 and Law 6834 of 24 October 2001.

In São Paulo State, Law 10,888, of 2001, deals with the disposal of potentially hazardous chemicals with general household waste. Batteries, bottles, aerosols and fluorescent lights are some of the products included in the law. Article 2 
states with manufacturers, distributors, importers, traders and dealers responsibility for reverse logistics of gathering these products.

In Santa Catarina State, by Law 11,347, of 2000, regulate collection, collection and disposal of potentially hazardous waste such as batteries and mercury lamps. Also, prohibits the disposal of them in landfills.

The state of Minas Gerais, by means of Law 13,766 of 2000, assigns to the State Environmental Policy Council to establish standards for collection, recycling and reuse of solid waste such as computer diskettes, batteries or fluorescent lamps, i.e. waste requiring specific procedures for disposal in the environment.

In the case of municipalities, in Americana, São Paulo, Law 3578, of 2001, blames about the disposal of batteries and light bulbs. The manufacturers, importers, distributors or retailers based in the city of Americana should be responsible for the correct destination within the current technologies and standards through procedures for the collection, reuse, recycling, treatment or disposal. This legislation has more operations such as distribution of products and tools for users to establishments that commercialized or any authorized dealer network.

In Campinas, São Paulo state, there is a ban on landfill disposal of fluorescent lamps that use mercury and the like. Law 11,294, of 2002, represents this prohibition.

In the city of Caxias do Sul, Rio Grande do Sul State, Law 5873 of 2002 discipline on the disposal and management of batteries and light bulbs attached to manufacturers and importers responsible for the reuse, recycling, treatment and disposal these wastes.

In summary, the states of Sao Paulo and Rio Grande do Sul, are the states that have laws more developed compared to the other from Brazil, but still need a serious national effort to change consumer behavior in relation to recycling of lamps fluorescent.

\section{Procedures and Methods}

To develop this work on the proper disposal of fluorescent lamps was administered questionnaire with 11 questions: ten dichotomous and one multi-item.

The items surveyed were: difference about incandescent and fluorescent lamps, recycling burnt out fluorescent lamps, the place the lamps dropped, knowledge about component of fluorescent lamp, knowledge that mercury contaminates the environment and is dangerous to health, knowledge that fluorescent lamps should be treated separately for disposal, about willing to go to a collection station for lamps appropriate destination, and companies actions about the obligation of specific.

However, all participants remained anonymous, established on the basis of convenience in a sample of 400 people. We obtain 240 participation (60\%) of sampling. The survey questions based on the literature review and readings. The appendix 1 shows the survey questionnaire.

The reliability of internal consistency evaluated using Cronbach's alpha with SPSS 18.0 PASWStatistics when responses are dichotomous (e.g. yes/no). In figure 1, the coefficient of Cronbach's alpha and standardized: respectively, 0.619 and 0.699 based on 10 items (variables). In this case, the scales showed consistency, because they are values recommended by the statistical literature.

\section{Results and Discussion}

We applied multivariate analysis technique known as multidimensional scaling (MDS) in order to find the behavior of respondents within a broader analysis. This method allows identifying, through a perceptual map, interlacing each of the questions, the degree of similarity, association, correlation, completeness or replacement. Visual information provided by MDS allows conduct the investigation taking into account what observed (Borg \& Groenen, 2005).

Figure 2 shows a perceptual map of the answers and how they intertwine with the questionnaire. Issues, reduced to two dimensions as the sixty respondents, formed clearly, four clusters indicating something obvious in the questions within each cluster. Note, for example, that the question Q2, In your opinion, the fluorescent lamps can be recycled? is close to Q9 that asks, Would you be willing to move to a collection station lamps located by example, in home centers or public agencies, for their correct destination, without any stimulation?

To evaluate the significance of this proximity, we applied the chi-square under the conditions presented in the contingency table of figure 3 finding the result of the chi-square test for independence among the issues on the same figure. The value of the test, 137.062, show high statistical significance ( $\mathrm{p}$-value close to zero), and there is independence between the responses of two issues, the MDS points in this case, a strong dependence of the responses. This can easily be seen when we consider that those who answered "no" to question 2, try to keep the same answer to 
question 9. It can be inferred that people who believe that fluorescent lamps can not be recycled, was also not willing to waste their time to move up a collection station of these bulbs without any incentive.

Contrary to this behavior, when evaluating the responses to question 8 , where, unlike the question 9, offering some incentive for disposal of lamps, the chi-square demonstrate some independence of responses between the question 2 and 8 (test value p-value 4.333 and 0.037 ) see figure 4 . The fact that someone claims not to believe that the bulbs can be recycled does not mean that they will not deliver bulbs into recycling containers for selective waste collection site through some incentive. It can be affirm, therefore, that the use of some incentive would increase the chances of someone going to give the bulbs a collection station. It is not, however, consciousness, but a mere question of economic advantage, a condition that can be verified when we cross the responses to questions 8 and 9.

An analysis of the behavior of respondents in questions 8 and 9 (figure 5) shows the chi-square (value 3.636 and p-value 0.57 ) that there is some dependence among the responses. Thus, the introduction of some incentive makes the decision to give or not the lamps in a collection station will also change. However, how does this change occur? Apparently, as stated earlier, people who would deny delivering bulbs into recycling containers for selective waste collection site when not receive some incentive; tend to change their minds when presenting an incentive.

Another situation that deserves analysis concerns questions 5 and 7, see figure 6, which have proximity in perceptual map. The significance of this proximity can be evaluated using the chi-square. The result of the chi-square (value 0.166 and p-value 0.684) shows a strong independence between the responses to questions 5 and 7 . The answer given by the individual in question 5 (the presence of mercury in them) does not change in question 7 . This shows that the knowledge that mercury is present develops the understanding that the lamps should have a different discard. Conversely, not being aware of the presence of mercury also indicates that they are unaware of different disposal.

The question 11 presented separately in the perceptual map, indicating it is an attribute that is not repeated in any of the other issues. This occur because over $78 \%$ believe that companies should implement programs to dispose of fluorescent lamps and cope with these environmental responsibilities. Nor do they believe that companies would create such an initiative without mandatory laws.

\section{Final Considerations}

Despite the favorable results from different knowledge about the environment, most people discard fluorescent lamps in the organic waste and considering the right place for disposal the selective collection and recycle post. Nevertheless these posts are not prepared for the effective processing and recycling of fluorescent lamps and components in Brazil. They only keep it for later processing by a company specializing in the recycling of this product, which can not be proven if it occurs. Over $90 \%$ respondents believe that companies should implement programs to dispose of fluorescent bulbs, and firms must also cope with these environmental responsibilities. They also criticize the companies would have no obligation to this initiative laws.

Businesses cater to various stakeholder, including customers, investors, and employees; to sensitized leaders to adopting green idea in their products and processes. Projecting a company's image as an innovator and different, as well as being socially and environmentally aware, could be a competitive advantage. People want to do business with green companies, so companies are creating massive advertising and web campaigns, to produce documented sustainability reports, to handle transparently externally, and communicating their efforts internally. We should start with an in-depth understanding of how today’s mainstream in attitudes, behaviors, lifestyle, and corporate expectations of consumers.

With this research, we found that the biggest obstacle to dispose of lamps is the ignorance of the public on recycling lamps, which has not found alternatives to dispose of properly in Brazil. Regarding the development of reverse logistics, the Government with the support of nongovernmental organizations and other shareholders should develop alternatives to promote environmental initiatives related to the proper disposal of fluorescent lamps. 


\section{References}

Associação Brasileira da Indústria de Iluminação - ABILUX. (2003). Lâmpadas e o meio ambiente: um panorama geral. Retrieved from http://www.asec.com.br/v3/docs/Doc_Encontro04_RobertoCastanon.pdf (in Portuguese).

Borg, I.; \& Groenem, P. J. F. Modern Multidimensional Scaling: Theory and Applications. New York: Springer, 2005.

Dahab, D. J., Gentry, J. W., \& Su, W. (1995). New Ways To Reach Non-Recyclers: An Extension Of The Model Of Reasoned Action To Recycling Behaviors. Advances in Consumer Research, 22(N.I), 251-256. Retrieved March 10, 2011, from http://www.acrwebsite.org/volumes/display.asp?id=7710

Das, S. K., Yedlarajiah, P., \& Narendra, R. (2000). An approach for estimating the end-of-life product disassembly effort and cost. International Journal of Production Research, 38(3), 657 - 673. doi:10.1080/002075400189356, http://tandfprod.literatumonline.com/doi/abs/10.1080/002075400189356, http://dx.doi.org/10.1080/002075400189356

DiLouie, C. (1994). The lighting management handbook. Lilburn, GA: Fairmont Press.

Environment Canada - Pollution and Waste - Environment and Health - Health Concerns. (2010, June 2). Retrieved March 17, 2011, from http://www.ec.gc.ca/mercure-mercury/default.asp?lang=En\&n=0EB35C98-1

Gerner, S., Kobeissi, D. B., Binder, Z., \& Descotes-Genon, B. (2005). Integrated approach for disassembly processes generation and recycling evaluation of an end-of-life product. International Journal of Production Research, 43(1), 195-222. doi:10.1080/00207540412331270414, http://dx.doi.org/10.1080/00207540412331270414

Gregory, J. R., \& Kirchain, R. E. (2008). A Framework for Evaluating the Economic Performance of Recycling Systems: A Case Study of North American Electronics Recycling Systems. Environmental Science \& Technology, 42(18), 6800-6808. doi:10.1021/es702666v, http://pubs.acs.org/doi/abs/10.1021/es702666v. http://dx.doi.org/10.1021/es702666v

Güngör, A., \& Gupta, S. M. (1999). Issues in environmentally conscious manufacturing and product recovery: a survey. Computers \& Industrial Engineering, 36(4), 811-853. doi: 10.1016/S0360-8352(99)00167-9, http://www.sciencedirect.com/science/article/pii/S0360835299001679.

Güngör, A., \& Gupta, S. M. (2002). Disassembly line in product recovery. International Journal of Production Research, 40(11), 2569 - 2589. doi:10.1080/00207540210135622, http://tandfprod.literatumonline.com/doi/abs/10.1080/00207540210135622.

Hoyer, W. D., \& Macinnis, D. J. (2009). Consumer Behavior. Mason, OH: Cengage Learning.

Hu, T., Sheu, J., \& Huang, K. (2002). A reverse logistics cost minimization model for the treatment of hazardous wastes. Transportation Research: Part E, 38(6), 457. doi:10.1016/S1366-5545(02)00020-0, http://dx.doi.org/10.1016/S1366-5545(02)00020-0

Johnson, M. R., \& Wang, M. H. (1995). Planning product disassembly for material recovery opportunities. International Journal of Production Research, 33(11), 3119. doi:10.1080/00207549508904864, http://dx.doi.org/10.1080/00207549508904864

Kinnaman, T. C. (2005). Why do Municipalities Recycle?, 5 Topics in Economic Analysis and Policy http://www.bepress.com/bejeap/topics/vol15/iss1/art5.

Lambert, A. J. D. (1997). Optimal disassembly of complex products. International Journal of Production Research, 35(9), 2509 - 2523. doi:10.1080/002075497194633, http://tandfprod.literatumonline.com/doi/abs/10.1080/002075497194633.

Li-Hsing, S. (2001). Reverse logistics system planning for recycling electrical appliances and computers in Taiwan. Resources, Conservation \& Recycling, 32(1), 55. doi:10.1016/S0921-3449(00)00098-7, http://dx.doi.org/10.1016/S0921-3449(00)00098-7

National Electrical Manufacturers Association. (n.d.). LampRecycle: Commercial Lighting: Lamp Recyclers. Retrieved March 10, 2011, from http://www.lamprecycle.org/Recyclers.php

Penev, K. D., \& de Ron, A. J. (1996). Determination of a disassembly strategy. International Journal of Production Research, 34(2), 495. doi:10.1080/00207549608904915, http://dx.doi.org/10.1080/00207549608904915

Polanco, S. L. C. (2007). A situação da destinação pós-consumo de lâmpadas de mercúrio no Brasil. Dissertação (Engenharia em Processos Bioquímicos). Instituto Mauá de Tecnologia (IMT), São Caetano do Sul. Retrieved from http://www.maua.br/arquivos/dissertacao/h/1dcf0e342efb1608be61ab2cb742b602 (in Portuguese). 
Procel Info. (2007, April 18). O aumento do uso das fluorescentes e a importância de seu correto descarte. (Retrieved September 17, 2009, from http://www.procelinfo.com.br/main.asp?View=\{83A07F04-90DC-407D-981E44ACC529A20B\}. in Portuguese.

Raposo, C., \& Roeser, H. M. (2000). Contaminação ambiental causada pelo descarte de lâmpadas fluorescentes. Revista Escola de Minas de Ouro Preto (REM), 53(1), 61-67.

Sanches, E. S. (2008). Logística Reversa de pós-consumo do setor de lâmpadas fluorescentes. In V Congresso Nacional de Engenharia Mecânica - CONEM 2008. Salvador. Retrieved from http://portal.anhembi.br/publique/media/artigo-conem2008.pdf

Schwartz, S. H., \& Fleishman, J. (1978). Personal Norms and the Mediation of Legitimacy Effects on Helping. Social Psychology, 41(4), 306-315. doi:10.2307/3033583, http://dx.doi.org/10.2307/3033583

Souza, M. T. S. D., Santos, C. C. D., \& Lima, M. D. C. F. (2007). Um estudo sobre o impacto ambiental da inovação tecnológica no setor de telecomunicações. (Vol. 1, p. 15). Presented at the IX ENGEMA: Encontro Nacional sobre Gestão Empresarial e Meio Amabiente, Curitiba: (in Portuguese). Retrieved from http://engema.up.edu.br/arquivos/engema/pdf/PAP0232.pdf

Spicer, A. J., \& Johnson, M. R. (2004). Third-party demanufacturing as a solution for extended producer responsibility. Journal of Cleaner Production, 12(1), 37. doi:10.1016/S0959-6526(02)00182-8, http://dx.doi.org/10.1016/S0959-6526(02)00182-8

US Environmental Protection Agency. (2010, November 18). Mercury-Containing Light Bulb (Lamp) Basic Information | Universal Waste | US EPA. Retrieved March 10, 2011, from http://www.epa.gov/osw/hazard/wastetypes/universal/lamps/basic.htm

Vitasek, K. (2010). Reverse Logistics. Glossary of Terms \& Definitions - Council of Supply Chain Management Professionals. Retrieved November 28, 2010, from http://cscmp.org/digital/glossary/glossary.asp

Reliability Statistics

\begin{tabular}{|c|c|c|}
\hline $\begin{array}{c}\text { Cronbach's } \\
\text { Alpha }\end{array}$ & $\begin{array}{c}\text { Cronbach's } \\
\text { Alpha Based } \\
\text { on } \\
\text { Standardized } \\
\text { Items }\end{array}$ & $\mathrm{N}$ of Items \\
\hline .619 & .699 & 10 \\
\hline
\end{tabular}

Figure 1. Reliability Matrix, Cronbach's Alpha Output of SPSS 18. 


\section{Derived Stimulus Configuration}

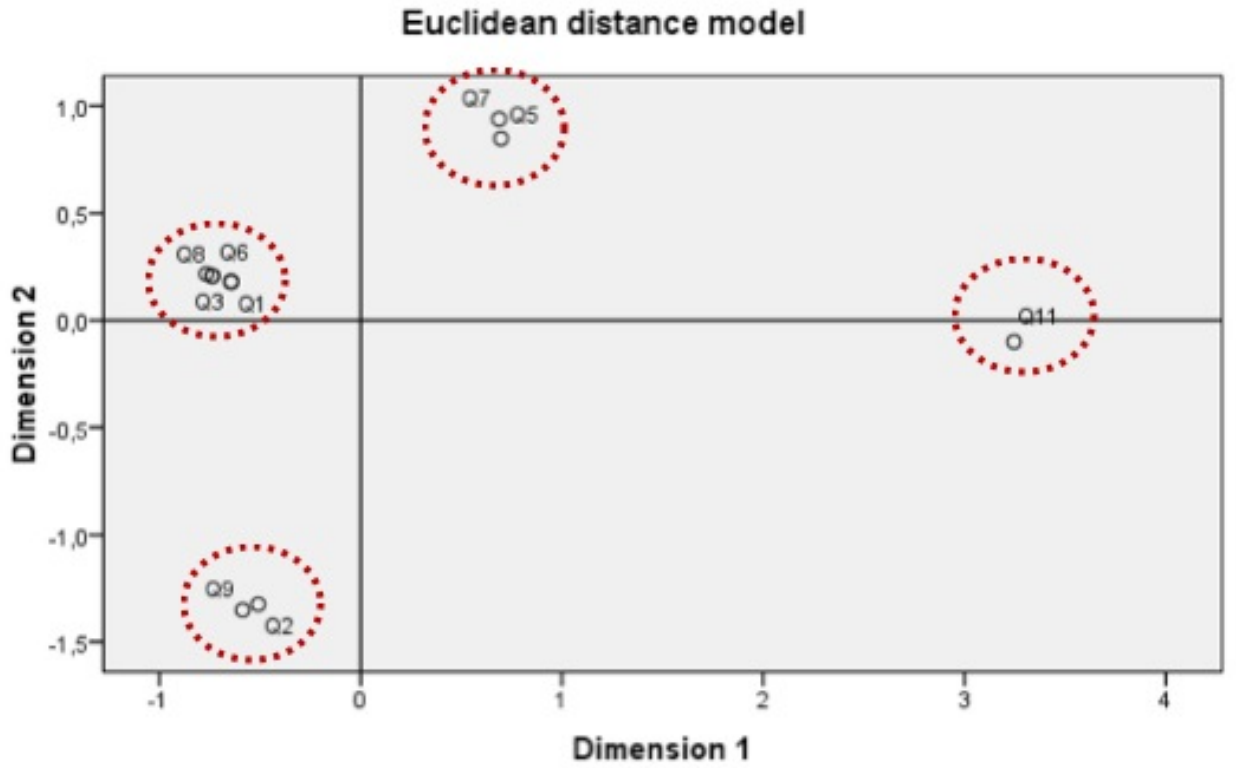

Figure 2. Multidimensional Scaling (MDS) from the Euclidean Distance criterion for binary variables (dichotomous).

\begin{tabular}{|c|c|c|c|c|c|}
\hline & \multicolumn{2}{|c|}{$\begin{array}{l}\text { Would you be willing to go to } \\
\text { a collection station for lamps } \\
\text { appropriate destination, } \\
\text { without a stimulus }\end{array}$} & \multirow[b]{2}{*}{ Total } \\
\hline & & & yes & no & \\
\hline \multirow{4}{*}{$\begin{array}{l}\text { In your opinion, the burnt } \\
\text { out fluorescent lamps can } \\
\text { be recycled? }\end{array}$} & yes & Count & 132 & 16 & 148 \\
\hline & & Expected Count & 88.8 & 59.2 & 148.0 \\
\hline & no & Count & 12 & 80 & 92 \\
\hline & & Expected Count & 55.2 & 36.8 & 92.0 \\
\hline \multirow[t]{2}{*}{ Total } & & Count & 144 & 96 & 240 \\
\hline & & Expected Count & 144.0 & 96.0 & 240.0 \\
\hline
\end{tabular}

Chi-Square Tests

\begin{tabular}{|l|c|r|r|r|r|}
\hline & Value & df & $\begin{array}{c}\text { Asymp. Sig. } \\
\text { (2-sided) }\end{array}$ & $\begin{array}{c}\text { Exact Sig. (2- } \\
\text { sided) }\end{array}$ & $\begin{array}{c}\text { Exact Sig. (1- } \\
\text { sided) }\end{array}$ \\
\hline Pearson Chi-Square & $137.062^{\mathrm{a}}$ & 1 & .000 & & \\
Continuity Correction $^{\mathrm{b}}$ & 133.908 & 1 & .000 & & \\
Likelihood Ratio & 150.406 & 1 & .000 & .000 & .000 \\
Fisher's Exact Test & & & & & \\
Linear-by-Linear & 136.491 & 1 & .000 & & \\
Association & 240 & & & & \\
N of Valid Cases & & & & & \\
\hline
\end{tabular}

a. 0 cells $(.0 \%)$ have expected count less than 5 . The minimum expected count is 36.80 .

b. Computed only for a $2 \times 2$ table

Figure 3. Chi-square test to compare questions 2 and 9. 


\begin{tabular}{|c|c|c|c|c|c|}
\hline & \multicolumn{2}{|c|}{$\begin{array}{l}\text { Would you be willing to go to } \\
\text { a collection station for lamps } \\
\text { appropriate destination, with } \\
\text { incentives in the form of rebates } \\
\text { to buy new lamps }\end{array}$} & \multirow[b]{2}{*}{ Total } \\
\hline & & & yes & no & \\
\hline \multirow{4}{*}{$\begin{array}{l}\text { In your opinion, the burn } \\
\text { out fluorescent lamps can } \\
\text { be recycled? }\end{array}$} & yes & Count & 140 & 8 & 148 \\
\hline & & Expected Count & 135.7 & 12.3 & 148.0 \\
\hline & no & Count & 80 & 12 & 92 \\
\hline & & Expected Count & 84.3 & 7.7 & 92.0 \\
\hline \multirow[t]{2}{*}{ Total } & & Count & 220 & 20 & 240 \\
\hline & & Expected Count & 220.0 & 20.0 & 240.0 \\
\hline
\end{tabular}

Chi-Square Tests

\begin{tabular}{|c|c|c|c|c|c|}
\hline & Value & df & $\begin{array}{c}\text { Asymp. Sig. } \\
\text { (2-sided) }\end{array}$ & $\begin{array}{l}\text { Exact Sig. (2- } \\
\text { sided) }\end{array}$ & $\begin{array}{l}\text { Exact Sig. (1- } \\
\text { sided) }\end{array}$ \\
\hline Pearson Chi-Square & $4.333^{\mathrm{a}}$ & 1 & .037 & \multirow{6}{*}{.053} & \multirow{6}{*}{.034} \\
\hline Continuity Correction $^{\mathrm{b}}$ & 3.391 & 1 & .066 & & \\
\hline Likelihood Ratio & 4.190 & 1 & .041 & & \\
\hline Fisher's Exact Test & & & & & \\
\hline $\begin{array}{l}\text { Linear-by-Linear } \\
\text { Association }\end{array}$ & 4.315 & 1 & .038 & & \\
\hline $\mathrm{N}$ of Valid Cases & 240 & & & & \\
\hline
\end{tabular}

a. 0 cells $(.0 \%)$ have expected count less than 5 . The minimum expected count is 7.67 .

b. Computed only for a $2 \times 2$ table

Figure 4. Chi-square test to compare questions 2 and 8.

\begin{tabular}{|c|c|c|c|c|c|}
\hline & & & \multicolumn{2}{|c|}{$\begin{array}{l}\text { Would you be willing to go to } \\
\text { a collection station for lamps } \\
\text { appropriate destination, } \\
\text { without a stimulus }\end{array}$} & \multirow[b]{2}{*}{ Total } \\
\hline & & & yes & no & \\
\hline \multirow{4}{*}{$\begin{array}{l}\text { Would you be willing to } \\
\text { go to a collection station } \\
\text { for lamps appropriate } \\
\text { destination, with } \\
\text { incentives in the form of } \\
\text { rebates to buy new lamps }\end{array}$} & \multirow[t]{2}{*}{ yes } & Count & 136 & 84 & 220 \\
\hline & & Expected Count & 132.0 & 88.0 & 220.0 \\
\hline & \multirow[t]{2}{*}{ no } & Count & 8 & 12 & 20 \\
\hline & & Expected Count & 12.0 & 8.0 & 20.0 \\
\hline \multirow[t]{2}{*}{ Total } & & Count & 144 & 96 & 240 \\
\hline & & Expected Count & 144.0 & 96.0 & 240.0 \\
\hline
\end{tabular}

Chi-Square Tests

\begin{tabular}{|c|c|c|c|c|c|}
\hline & Value & df & $\begin{array}{l}\text { Asymp. Sig. } \\
\text { (2-sided) }\end{array}$ & $\begin{array}{l}\text { Exact Sig. (2- } \\
\text { sided) }\end{array}$ & $\begin{array}{l}\text { Exact Sig. (1- } \\
\text { sided) }\end{array}$ \\
\hline Pearson Chi-Square & $3.636^{\mathrm{a}}$ & 1 & .057 & \multirow{6}{*}{.093} & \multirow{6}{*}{.049} \\
\hline Continuity Correction $^{\mathrm{b}}$ & 2.784 & 1 & .095 & & \\
\hline Likelihood Ratio & 3.548 & 1 & .060 & & \\
\hline Fisher's Exact Test & & & & & \\
\hline $\begin{array}{l}\text { Linear-by-Linear } \\
\text { Association }\end{array}$ & 3.621 & 1 & .057 & & \\
\hline $\mathrm{N}$ of Valid Cases & 240 & & & & \\
\hline
\end{tabular}

a. 0 cells $(.0 \%)$ have expected count less than 5 . The minimum expected count is 8.00 .

b. Computed only for a $2 \times 2$ table

Figure 5. Chi-square test to compare the questions 8 and 9. 


\begin{tabular}{|c|c|c|c|c|c|}
\hline & & & \multicolumn{2}{|c|}{$\begin{array}{l}\text { Do you know that fluorescent } \\
\text { lamps should be treated } \\
\text { separately for disposal? }\end{array}$} & \multirow[b]{2}{*}{ Total } \\
\hline & & & yes & no & \\
\hline \multirow{4}{*}{$\begin{array}{l}\text { Do you know that one } \\
\text { component of fluorescent } \\
\text { lamp is mercury? }\end{array}$} & yes & Count & 108 & 56 & 164 \\
\hline & & Expected Count & 106.6 & 57.4 & 164.0 \\
\hline & no & Count & 48 & 28 & 76 \\
\hline & & Expected Count & 49.4 & 26.6 & 76.0 \\
\hline \multirow[t]{2}{*}{ Total } & & Count & 156 & 84 & 240 \\
\hline & & Expected Count & 156.0 & 84.0 & 240.0 \\
\hline
\end{tabular}

Chi-Square Tests

\begin{tabular}{|c|c|c|c|c|c|}
\hline & Value & df & $\begin{array}{l}\text { Asymp. Sig. } \\
\text { (2-sided) }\end{array}$ & $\begin{array}{l}\text { Exact Sig. (2- } \\
\text { sided) }\end{array}$ & $\begin{array}{l}\text { Exact Sig. (1- } \\
\text { sided) }\end{array}$ \\
\hline Pearson Chi-Square & $.166^{\mathrm{a}}$ & 1 & .684 & \multirow{6}{*}{.771} & \multirow{6}{*}{.395} \\
\hline Continuity Correction $^{\mathrm{b}}$ & .069 & 1 & .793 & & \\
\hline Likelihood Ratio & .165 & 1 & .684 & & \\
\hline Fisher's Exact Test & & & & & \\
\hline $\begin{array}{l}\text { Linear-by-Linear } \\
\text { Association }\end{array}$ & .165 & 1 & .684 & & \\
\hline $\mathrm{N}$ of Valid Cases & 240 & & & & \\
\hline
\end{tabular}

a. 0 cells $(.0 \%)$ have expected count less than 5 . The minimum expected count is 26.60 .

b. Computed only for a $2 \times 2$ table

Figure 6. Chi-square test to compare the questions 5 and 7.

\section{Appendix}

Appendix 1. Questionnaire

Please answer the following questions by ticking in the appropriate box.

1) Do you know how to differentiate incandescent bulbs for fluorescent lamps?

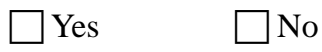

2) In your opinion, the burnt out fluorescent lamps can be recycled?
$\square$ Yes
$\square$ No

3) Have you discard any fluorescent lamp? (If your answer is no, skip to question 5).

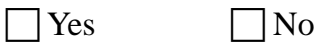

4) In which place the bulb was dropped?

$\square$ General household waste

Land abandoned or sidewalks

Selective-collecting stations

Stations centralized collection of light bulbs.

5) Do you know that one component of fluorescent lamp is mercury?
$\square$ Yes
No

6) Do you know that mercury contaminates the environment and is dangerous to health?
$\square$ Yes
No 
7) Do you know that fluorescent lamps should be treated separately for disposal?

$\square$ Yes $\quad \square$ No

8) Would you be willing to go to a collection station for lamps appropriate destination, with incentives in the form of rebates to buy new lamps?
$\square$ Yes
No

9) Would you be willing to go to a collection station for lamps appropriate destination, without a stimulus?

$\square$ Yes $\quad \square$ No

10) In your opinion, all companies should be environmental consciousness and support the initiative to collaborate with programs for disposal of fluorescent lamps?

$\square$ Yes $\quad \square$ No

11) Do you think that companies take the action mentioned in the previous question without the obligation of specific laws?

$\square$ Yes $\quad \square$ No 